\title{
PENIPISAN PIPA KETEL AKIBAT ELEMEN KOROSIF AIR
}

\section{BOILER PIPE THINNING DUE TO CORROSIVE ELEMENT OF WATER}

\author{
M. N. Setia Nusa ${ }^{(1)}$, Hernadi ${ }^{(2)}$. \\ Peneliti Bidang Pengujian Material \\ Balai Besar Teknologi Kekuatan dan Struktur-BPP Teknologi \\ e-mail: naswir.setia@bppt.go.id ${ }^{(1)}$, hernadiap@yahoo.com ${ }^{(2)}$
}

\begin{abstract}
Abstrak
Inspeksi dan pengujian dilakukan untuk mengetahui fenomena metalurgis yang terjadi terhadap pipa ketel uap yang sudah beroperasi beberapa tahun secara terus menerus pada suhu $560^{\circ} \mathrm{C}$. Penelitian juga dimaksudkan untuk mengetahui kelayakan operasional pipa tersebut dan untuk menghindari terjadinya kerusakan yang tidak terdeteksi

Investigasi pipa-pipa tersebut juga dilakukan di laboratorium dengan metode analisa struktur mikro, pemeriksaan kerak, uji tarik, uji bending, uji kekerasan dan ketebalan.

Dari analisa struktur mikro, pipa ketel berada pada kondisi ferrit spheroidisasi perlit dengan lapisan kerak yang cukup tebal serta mengandung grafit. Selain itu juga terjadi serangan korosi merata dan korosi sumuran. Hasil uji tarik dan hasil uji bengkok masih normal (memenuhi standar). Hasil uji kekerasan terjadi penurunan nilai yang signifikan dibanding standar, demikian juga pada ketebalan pipa terjadi penipisan akibat dari adanya proses korosi.
\end{abstract}

Kata Kunci: Pipa ketel, speroidisasi, korosi, penipisan.

\begin{abstract}
Inspection and testing is done to determine the metallurgical phenomena that occur on the boiler pipes that have been operating several years continuously at a temperature of $560^{\circ} \mathrm{C}$. The study is also intended to determine the operational feasibility of the pipeline and to avoid undetected damage.

Investigation of these pipes is also carried out in the laboratory with micro-structure analysis method, inspection crust, tensile test, bending test, hardness and thickness test.

From the analysis of the microstructure, boiler pipes are in condition ferrite pearlite spheroidization with a crust that is thick and contains graphite. In addition, The pipes are attacked by uniform and pitting corrosion. The results of tensile and bending tests are still normal (standard). The hardness test results show significant values compared to the standard, as well as the thickness of the pipe thinning as a result of the corrosion process.
\end{abstract}

Keyword: Boiler pipe, spheroidization, corrosion, thinning

\section{PENDAHULUAN}

Ketel uap adalah suatu perangkat utama pembangkit uap yang berfungsi mengubah air menjadi uap, proses perubahan air menjadi uap terjadi dengan memanaskan air yang berada didalam pipa-pipa dengan memanfaatkan panas dari hasil pembakaran bahan bakar. Pembakaran dilakukan secara rutin didalam ruang bakar dengan mengalirkan bahan bakar dan udara dari luar, uap yang dihasilkan ketel adalah uap superheat dengan tekanan dan temperatur yang tinggi.

Jumlah produksi uap tergantung pada luas permukaan pemindah panas, laju aliran, dan panas pembakaran yang diberikan, ketel yang konstruksinya terdiri dari pipa-pipa berisi air disebut dengan water tube boiler. Pada unit pembangkit, ketel juga biasa disebut dengan steam generator (pembangkit uap) mengingat arti kata ketel hanya pendidih, sementara pada kenyataannya dari ketel dihasilkan uap superheat bertekanan tinggi. 


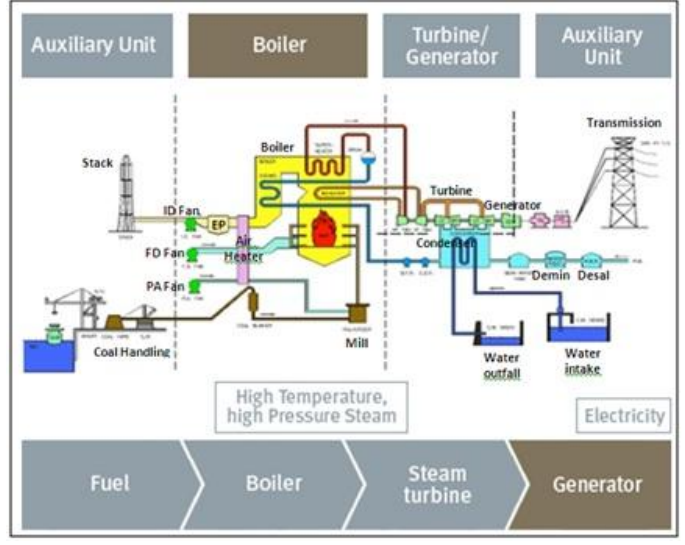

Gambar 1 : Tata letak Pulverized Coal (PC) Boiler \& Circulating Fluidized Boiler (CFB)

Air sebagai fluida kerja diisikan ke boiler menggunakan pompa air pengisi melalui pipa economiser dan ditampung didalam steam drum. Economiser adalah alat yang merupakan pemanas air terakhir sebelum masuk ke drum. Di dalam economiser air menyerap panas gas buang yang keluar dari superheater sebelum dibuang ke atmosfir melalui cerobong. Dari header bawah air didistribusikan ke pipapipa pemanas (riser) yang tersusun membentuk dinding ruang bakar boiler (gambar 1). Didalam riser air mengalami pemanasan dan naik ke drum kembali akibat perbedaan temperatur.

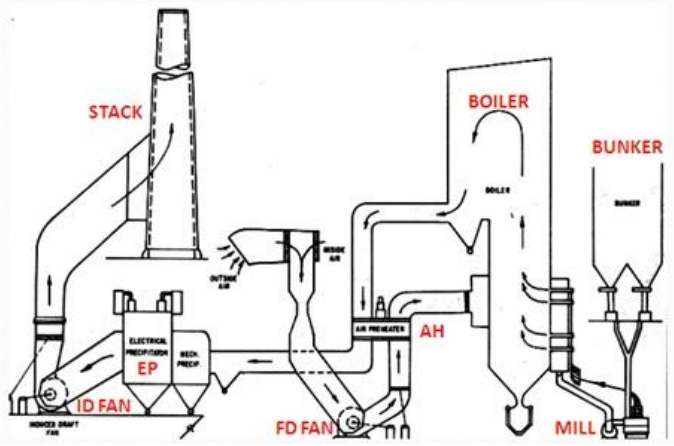

Gambar 2 : Skema Balanced Draft Boiler dan siklus air.

Perpindahan panas dari api (flue gas) ke air di dalam pipa-pipa boiler terjadi secara radiasi, konveksi dan konduksi. Akibat pemanasan selain temperatur naik hingga mendidih juga terjadi sirkulasi air secara alami (gambar 2), yakni dari drum turun melalui down comer ke header bawah dan naik kembali ke drum melalui pipa-pipa riser. Adanya sirkulasi ini sangat diperlukan agar terjadi pendinginan terhadap pipa-pipa pemanas dan mempercepat proses perpindahan panas. Kecepatan sirkulasi akan berpengaruh terhadap produksi uap dan kenaikan tekanan serta temperaturnya.

Untuk menciptakan suatu keamanan dan keselamatan dalam pengoperasian boiler, maka harus dilakukan inspeksi yang optimal dan dioperasikan berdasarkan pedoman atau batasan-batasan pengoperasian yang telah ditentukan. Tujuan penelitian ini untuk mengevaluasi kondisi material pipa dan menelusuri fenomena yang terjadi pada pipa-pipa ketel dengan cara melakukan: pemeriksaan struktur mikro, pengujian kekerasan, pengujian tarik, pengujian bengkok, pengukuran ketebalan dan pemeriksaan kerak, terhadap pipa ketel pada:

1. Secondary Superheater

2. Economizer Horizontal \& vertical

3. Platen Superheater F/S (PLSHF)

4. Primary Superheater

5. Wall Tube F/S (WTF)

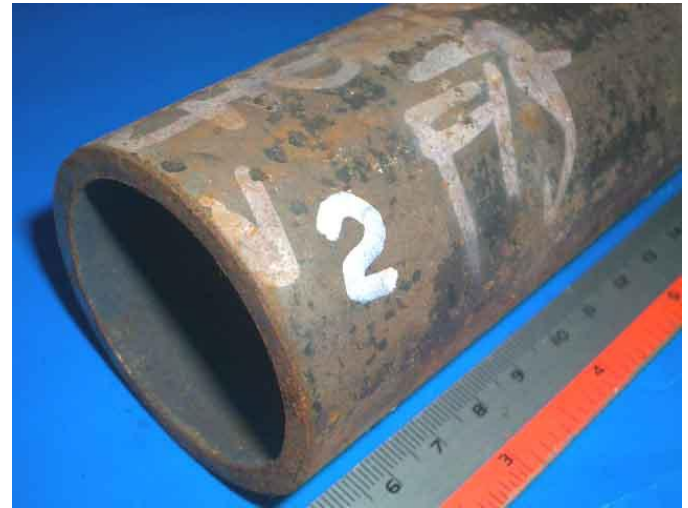

Gambar 3 : Sampel tube Secondary Super heater

\section{Data teknis tube Boiler:}

- Desain Pressure : 1704 Psi

- Final Steam Temp. : $560^{\circ} \mathrm{C}$

- Year Built : 1993

- Capacity : 300 Ton/hour

\section{METODE PENELITIAN}

Metode penelitian meliputi pemeriksaan dan pengujian sebagai berikut : 
Pemeriksaan Fraktografi menggunakan "Stereo Microscope" (mengacu pada ASTM E 340): Untuk memeriksa permukaan kerusakan dan mendeteksi jenis kerusakan serta mencari awal dari kerusakan, pemeriksaan makro fraktografi merupakan pemeriksaan pada permukaan kerusakan/ perpatahan, yang bertujuan untuk mengetahui penyebab terjadinya kerusakan atau patahnya benda uji pada sampel yang akan diteliti. Kemudian dari gambar yang didapatkan akan terlihat bentuk kerusakan atau jenis perpatahan serta awal dari terjadinya patahan.

Pemeriksaan Metalografi menggunakan mikroskop optik "Metalloplan" (mengacu pada ASTM E 407): Untuk mengamati struktur mikro dan makro serta mengamati kemungkinan adanya cacat mikro yang tidak terdeteksi oleh alat lain dan untuk mengetahui kondisi, adanya retakan, inklusi, rongga udara (porositas) serta bentuk struktur dan kerusakannya. Hal ini dapat dilihat dengan menggunakan mikroskop optik. Analisa dengan melihat struktur mikro untuk mengetahui kondisi material ini dengan menggunakan mikroskop dengan perbesaran 50X s/d 500X. Dari pemeriksaan struktur mikro juga dapat diketahui fasa dan bentuk struktur bahan, apakah sesuai dengan spesifikasi maupun persyaratan operasionil yang diinginkan.

Proses analisa metalografi ini, diawali dengan proses pemilihan lokasi pengambilan sampel, hal ini harus dilakukan dengan cermat karena bila kurang berhati-hati, maka hasil yang diharapkan tidak dapat dicapai. Prosesnya diawali dengan penghalusan permukaan dengan penggerindaan dan polishing, proses ini dilakukan dengan penghalusan permukaan benda uji atau sampel mulai dari tingkat kekasaran permukaan kertas amplas yang kasar sampai dengan yang sangat halus (grade 80, 120, 240, 360 dan 400) serta dilanjutkan dengan penghalusan dengan diamond pasta dengan kehalusan $6,3,1 \mathrm{~s} / \mathrm{d} 1 / 4$ mikron. Kemudian setelah permukaannya benar-benar halus (seperti cermin) tahap selanjutnya adalah tahap pengetsaan.

Pada tahap ini zat kimia yang akan digunakan untuk mengetsa tergantung pada jenis bahan logam yang akan diperiksa sesuai strukturnya. Tahap akhir yang dilakukan untuk memperoleh gambar yang jelas tentang bentuk dan ukuran struktur mikro adalah pengamatan dengan menggunakan mikroskop optik.

Uji Kekerasan menggunakan alat "Frank Finotest" (mengacu pada SNI 190406) dengan beban $5 \mathrm{kgf}$ dan waktu 15 detik dengan indentor menggunakan piramid, pengujian dilakukan pada area sekitar kerusakan atau area yang dianggap mewakili untuk mengevaluasi perubahan nilai kekerasan yang terjadi setelah beroperasi pada material tersebut apakah masih dalam kekerasan standard yang diizinkan atau seberapa jauh perubahan kekerasan yang terjadi akibat dari pengoperasian atau pengaruh lainnya.

Pemeriksaan Komposisi Kimia menggunakan alat "OES Metorex Arc-Met 930" (mengacu pada ASTM A 751) : Untuk meneliti kandungan elemen yang ada pada material dasar dari pipa, dengan mengambil sampel untuk mengetahui apakah komposisi kimia yang diinformasikan sampai dengan 16 unsur dari turbin blade yang digunakan sesuai dengan spesifikasi komposisi kimia yang diizinkan/ standard.

Analisa deposit menggunakan alat EDAX (Energy Dispersive X-Ray Analysis): Untuk mendeteksi adanya elemen yang berpengaruh terhadap terjadinya kerusakan, seperti elemen korosif dan mengetahui komposisi kerak yang terdapat pada material uji untuk mengetahui unsur penyebab terjadinya kerak pada permukaan luar maupun bagian dalam material.

\section{HASIL PEMERIKSAAN DAN PENGUJIAN}

\section{PEMERIKSAAN METALOGRAFI}

Sampel untuk pemeriksaan metalografi diambil dari potongan pipa ketel yang tertera pada gambar 3 pada diameter luar, bagian tengah dan diameter dalam.

Pada gambar 4 merupakan struktur mikro dari potongan melintang tube Secondary Superheater F/S $16^{\text {th }}$ Row pada sisi dalam berupa ferrite dan spheroidisasi pearlite, pada permukaan terlihat adanya lapisan kerak yang cukup tebal, dan serangan korosi sumuran (pitting corrosion). Nilai kekerasan: $132 \mathrm{HV}$. 


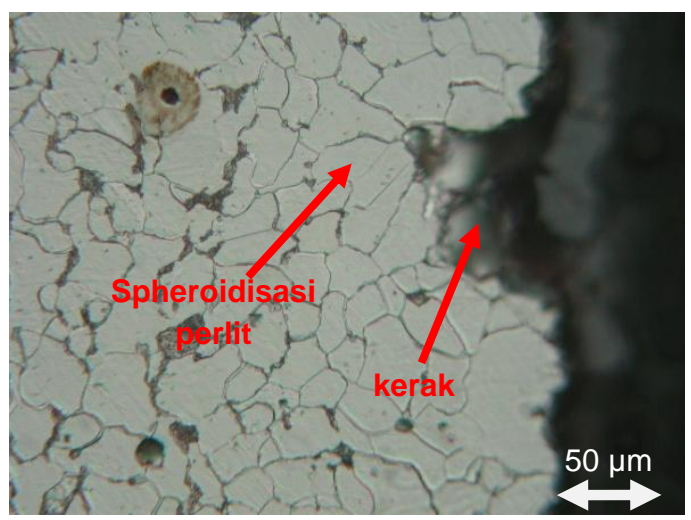

Gambar 4 : Struktur mikro potongan melintang tube Secondary Superheater F/S $16^{\text {th }}$ Row pada sisi dalam. Etsa: Nital $2 \%$.

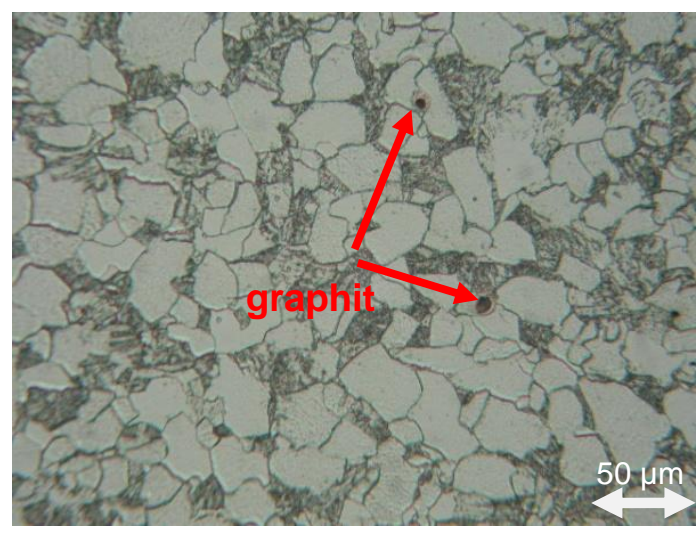

Gambar 5 : Struktur mikro tube Economizer Horizontal F/S pada bagian tengah. Etsa : Nital 2\%.

Pada gambar 5 struktur mikro tube Economizer Horizontal F/S pada bagian tengah berupa ferrite dan spheroidisasi pearlite yang mengan-dung graphite (tanda panah). Nilai kekerasan : $122 \mathrm{HV}$.

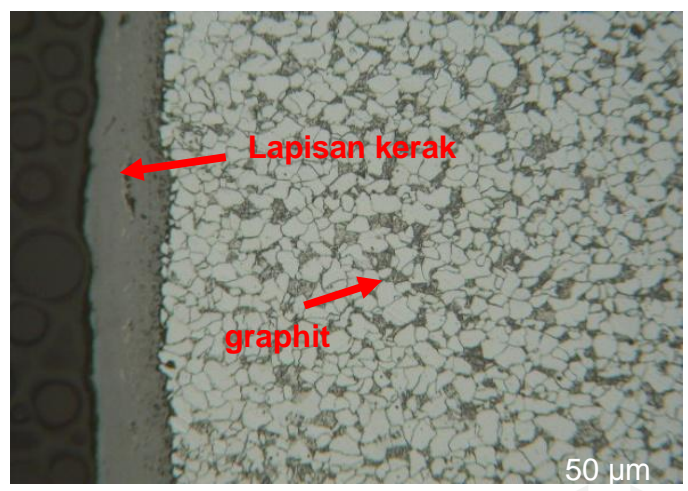

Gambar 6 : Struktur mikro potongan melintang dari gambar 3 tube Secondary Superheater Row sisi luar terdapat lapisan kerak.
Gambar 6 adalah struktur mikro dari potongan melintang pipa dari gambar 3 tube Secondary Superheater Row sisi luar berupa ferrite dan spheroidisasi pearlite, pada permukaan terlihat lapisan kerak yang cukup tebal serta terdapat graphit serta terdapat serangan korosi merata (general corrosion).

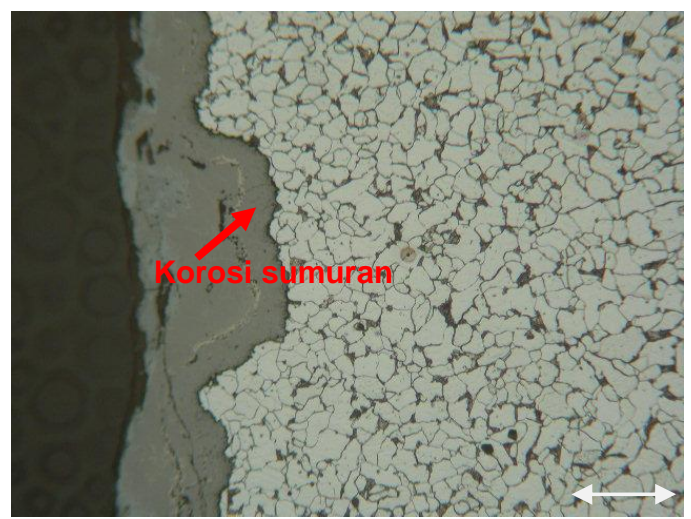

Gambar 7 : Korosi sumuran pada struktur mikro potongan melintang dari gambar 3 tube Secondary Superheater Row sisi luar.

Pada gambar 7 struktur mikro potongan melintang dari material pipa pada gambar 4 tube Secondary Superheater Row sisi luar berupa ferrite dan spheroidisasi pearlite, pada permukaan terlihat lapisan kerak yang cukup tebal dan terjadi serangan korosi sumuran (pitting corrosion).

Etsa : Nital 8\%.

Nilai kekerasan : $123 \mathrm{HV}$.

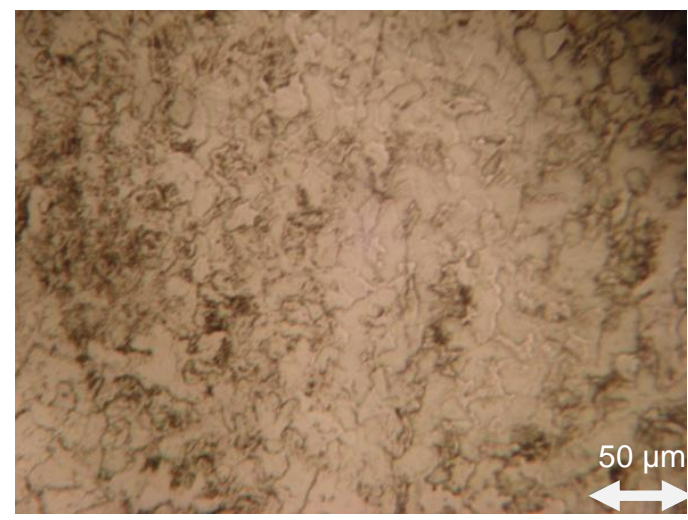

Gambar 8 : Struktur mikro Elbow Primary Superheater. Etsa : Nital 8\%.

Pada gambar 8. struktur mikro Elbow Primary Superheater adalah berupa ferrite 
dan spheroidisasi pearlite (kelas C, menurut ERA Technology) ${ }^{(14)}$, tidak terlihat adanya creep void atau kerusakan lainnya.

\section{PENGUJIAN MEKANIS}

Data teknis standard kuat tarik dan kekerasan dari specimen uji ditunjukkan pada table 1. Sedangkan hasil pengujian tarik, bending, kekerasan dan ketebalan ditunjukkan pada table 2, 3, 4 dan 5 .

Hasil pengujian kekerasan di lapangan pipa-pipa ketel ditunjukkan pada table 6.

Hasil pengujian kekerasan dilaksanakan dengan menggunakan Mesin Frank Finotest, dengan beban $2 \mathrm{~kg} / \mathrm{mm} 2$ dan standar pengujian DIN 50133.

Tabel 1. Data Teknis Standard Kuat Tarik dan Kekerasan) $)^{(17)}$

\begin{tabular}{|c|c|c|c|c|c|}
\hline No. & Location & $\begin{array}{c}\text { Tensile } \\
\text { Strength } \\
\text { (MPa) }\end{array}$ & $\begin{array}{c}\text { Yield } \\
\text { Strength } \\
\text { (MPa) }\end{array}$ & $\begin{array}{c}\text { Elong- } \\
\text { ation (\%) }\end{array}$ & $\begin{array}{c}\text { Hardness } \\
\text { (HV) }\end{array}$ \\
\hline 1 & Secondary Super Heater F/S $1^{\text {st }}$ Row & Min. 415 & Min. 205 & Min. 30 & Max. 170 \\
\hline 2 & Secondary Super Heater F/S $16^{\text {th }}$ Row & Min. 415 & Min. 205 & Min. 30 & Max. 170 \\
\hline 3 & Economizer Horizontal F/S & Min. 415 & Min. 255 & Min. 22 & --- \\
\hline 4 & Economizer Vertical F/S & Min. 415 & Min. 255 & Min. 22 & --- \\
\hline 5 & Platent Super Heater F/S & Min. 415 & Min. 205 & Min. 30 & Max. 170 \\
\hline 6 & Primary Super Heater F/S $1^{\text {st }}$ Row & Min. 415 & Min. 205 & Min. 30 & Max. 170 \\
\hline 7 & Primary Super Heater F/S $20^{\text {th }}$ Row & Min. 415 & Min. 255 & Min. 22 & --- \\
\hline 8 & Wall Tube F/S & Min. 415 & Min. 255 & Min. 22 & --- \\
\hline
\end{tabular}

Tabel 2. Hasil Pengujian Tarik

\begin{tabular}{|c|c|c|c|c|c|}
\hline No & Location & $\begin{array}{c}\text { Tensile } \\
\text { (Mpa) }\end{array}$ & $\begin{array}{c}\text { Yield } \\
\text { (Mpa) }\end{array}$ & $\begin{array}{c}\text { Elongation } \\
(\%)\end{array}$ & $\begin{array}{c}\text { Reduction } \\
(\%)\end{array}$ \\
\hline 1 & Secondary Super Heater F/S $1^{\text {st }}$ Row & 484.46 & 289.56 & 27.50 & 70.57 \\
\hline 2 & Secondary Super Heater F/S $16^{\text {th }}$ Row & 592.94 & 357.65 & 26.20 & 64.74 \\
\hline 3 & Economizer Horizontal F/S & 436.15 & 293.56 & 32.60 & 68.09 \\
\hline 4 & Economizer Vertical F/S & 480.00 & 340.00 & 28.26 & 67.55 \\
\hline 5 & Platent Super Heater F/S & 492.88 & 346.84 & 29.55 & 69.95 \\
\hline 6 & Primary Super Heater F/S $1^{\text {st }}$ Row & 513.44 & 397.08 & 25.04 & 67.19 \\
\hline 7 & Primary Super Heater F/S $20^{\text {th }}$ Row & 432.72 & 297.50 & 33.30 & 67.24 \\
\hline 8 & Wall Tube F/S & 435.69 & 314.27 & 31.10 & 65.52 \\
\hline
\end{tabular}

Tabel 3. Hasil Pengujian Bending

\begin{tabular}{|c|c|c|c|c|c|c|}
\hline No. & Location & $\begin{array}{c}\text { Width } \\
\text { (mm) }\end{array}$ & $\begin{array}{l}\text { Thick } \\
\text { (mm) }\end{array}$ & $\begin{array}{c}\text { Angle } \\
\text { of } \\
\text { Bend }\end{array}$ & $\begin{array}{l}\text { Dia. of } \\
\text { Former }\end{array}$ & $\begin{array}{c}\text { Open } \\
\text { Defect } \\
\text { (mm) }\end{array}$ \\
\hline 1 & Secondary Super Heater F/S $1^{\text {st }}$ Row & 25.15 & 7.30 & $180^{\circ}$ & $30 \mathrm{~mm}$ & NONE \\
\hline 2 & Secondary Super Heater F/S $16^{\text {th }}$ Row & 25.30 & 8.50 & $180^{\circ}$ & $30 \mathrm{~mm}$ & NONE \\
\hline 3 & Economizer Horizontal / vertical F/S & 25.53 & 4.75 & $180^{\circ}$ & $30 \mathrm{~mm}$ & NONE \\
\hline 5 & Platent Super Heater F/S & 25.50 & 4.20 & $180^{\circ}$ & $30 \mathrm{~mm}$ & NONE \\
\hline 6 & Primary Super Heater F/S $1^{\text {st }}$ Row & 25.80 & 4.30 & $180^{\circ}$ & $30 \mathrm{~mm}$ & NONE \\
\hline 7 & Primary Super Heater F/S $20^{\text {th }}$ & 24.96 & 4.40 & $180^{\circ}$ & $30 \mathrm{~mm}$ & NONE \\
\hline 8 & Wall Tube F/S & 24.70 & 5.30 & $180^{\circ}$ & $30 \mathrm{~mm}$ & NONE \\
\hline
\end{tabular}


Tabel 4. Hasil Pengujian Kekerasan (pipa yang dipotong)

\begin{tabular}{clccc}
\hline No. Location & \multicolumn{3}{c}{ Nilai Kekerasan (HV) } \\
\cline { 3 - 5 } & & $\varnothing$ Luar & Tengah & $\varnothing$ Dalam \\
\hline 1 & $\begin{array}{l}\text { Secondary Super Heater F/S 1 } \\
\text { Sow }\end{array}$ & 152 & 151 & 148 \\
& $\begin{array}{l}\text { Row } \\
2\end{array}$ & Secondary Super Heater F/S 16 & & \\
& Row & 134 & 131 & 132 \\
3 & Economizer Horizontal F/S & 118 & 122 & 117 \\
4 & Economizer Vertical F/S & 116 & 123 & 122 \\
5 & Platent Super Heater F/S & 142 & 152 & 142 \\
6 & Primary Super Heater F/S 1 $1^{\text {st }}$ Row & 153 & 164 & 164 \\
7 & Primary Super Heater F/S 20 & 122 & 123 & 113 \\
& Row & & & \\
8 & Wall Tube F/S & 118 & 122 & 135 \\
\hline
\end{tabular}

Tabel 5. Hasil Pengujian Ketebalan

\begin{tabular}{|c|c|c|c|c|}
\hline No. & Location & $\begin{array}{l}\text { Thick } \\
\text { (mm) }\end{array}$ & $\begin{array}{c}\text { Standard } \\
(\mathrm{mm})\end{array}$ & $\begin{array}{c}\text { Penipisan } \\
(\%)\end{array}$ \\
\hline 1 & Secondary Super Heater F/S $1^{\text {st }}$ Row & 7.30 & 8.00 & 8.75 \\
\hline 2 & Secondary Super Heater F/S $16^{\text {th }}$ Row & 8.50 & 9.00 & 5.56 \\
\hline 3 & Economizer Horizontal / vertical F/S & 4.75 & 5.00 & 5.00 \\
\hline 5 & Platent Super Heater F/S & 4.20 & 5.00 & 16.00 \\
\hline 6 & Primary Super Heater F/S $1^{\text {st }}$ Row & 4.30 & 5.00 & 14.00 \\
\hline 7 & Primary Super Heater F/S $20^{\text {th }}$ Row & 4.40 & 5.00 & 12.00 \\
\hline 8 & Wall Tube F/S & 5.30 & 6.00 & 11.67 \\
\hline
\end{tabular}

Tabel 6. Hasil Uji Kekerasan (dilapangan)

\begin{tabular}{clc}
\hline No. & \multicolumn{1}{c}{ Location } & Hardness (HV) \\
\hline 1 & Elbow Super Heater Link Platen 2 & 137.0 \\
2 & Elbow Primary Super Heater Link Steam Drum & 123.0 \\
3 & Tube Primary Super Heater Link Steam Drum & 119.0 \\
\hline & & \\
SUPER HEATER & $123.0-128.0$ \\
\hline 4 & Platent \& Scondary Super Heater Row 10 & $127.0-132.0$ \\
6 & Secondary Super Heater Panel 23 Row 1 \& Row 4 & $155.0-158.0$ \\
8 & Secondary Super Heater Panel 24 Row 12 \& row 16 & $101.0-110.0$ \\
10 & Primary Super Heater Panel 6 \& 9 Row 20 & $105.0-137.0$ \\
12 & Primary Super Heater Panel 46 Row 1 \& row 2 & $\mathbf{1 2 3 . 0 ~ s / d ~ 1 3 6 . 0}$ \\
\hline HEADER dengan kekerasan
\end{tabular}

STEAM DRUM

$\begin{array}{llc}20 & \text { Steam Drum Head 1 \& head 2 } & 108.0-112.0 \\ 22 & \text { Steam Drum Shell 1 } & 131.0\end{array}$




\begin{tabular}{lll}
\hline \multicolumn{2}{l}{ BURNER WATER WALL } & \\
\cline { 1 - 2 } 23 & Elbow & $150.0-155.0$ \\
28 & Front Water Wall & $125.0-138.0$ \\
\hline HEADER & \\
\hline $1 \quad$ Inlet \& outlet Platent Secondary \& Prymary S/H Header & $131.3-161.3$ \\
7 & Steam Drum & $142.0-155.0$ \\
10 & Elbow A, B, C & $134.8-162.8$ \\
13 & East \& west Side Water Wall Lower Header & $131.3-139.3$ \\
17 & Nort \& South Water Wall Side Upper Header A,B,C & $115.3-125.7$ \\
23 & North \& South Side WW Lower Header & $135.0-168.0$ \\
37 & Economizer Header & $142.0-165.0$ \\
\hline
\end{tabular}

\section{PEMERIKSAAN KERAK (SCALE)}

Secara rinci hasil pemeriksaan dan pengujian terhadap kerak (scale) yang melekat pada dinding luar dan dalam tube Boiler pada table 7.

Table 7. Ketebalan Kerak (Scale)

\begin{tabular}{|c|c|c|c|}
\hline \multirow{2}{*}{$\begin{array}{c}\text { No } \\
\text {. }\end{array}$} & \multirow[t]{2}{*}{ Location } & \multicolumn{2}{|c|}{ Ketebalan Deposit (mm) } \\
\hline & & Dinding Luar & Dinding Dalam \\
\hline 1 & Secondary Super Heater F/S $1^{\text {st }}$ Row & 0.5375 & 0.1825 \\
\hline 2 & Secondary Super Heater F/S $16^{\text {th }}$ Row & 0.7027 & 0.2130 \\
\hline 3 & Economizer Horizontal F/S & 0.0392 & 0.0575 \\
\hline 4 & Economizer Vertical F/S & 0.0335 & 0.0175 \\
\hline 5 & Platent Super Heater F/S & 0.2490 & 0.0829 \\
\hline 6 & Primary Super Heater F/S $1^{\text {st }}$ Row & 0.2968 & 0.0916 \\
\hline 7 & Primary Super Heater F/S $20^{\text {th }}$ Row & 0.0974 & 0.0089 \\
\hline 8 & Wall Tube F/S & 0.0805 & 0.0849 \\
\hline
\end{tabular}

Table 8. Analisa Kerapatan Kerak (Scale)

\begin{tabular}{clcc}
\hline No & \multicolumn{1}{c}{ Location } & \multicolumn{2}{c}{ Kerapatan Deposit $\left(\mathbf{m g} / \mathbf{c m}^{\mathbf{2}}\right)$} \\
\cline { 3 - 4 } . & & Dinding Luar & Dinding Dalam \\
\hline 1 & Secondary Super Heater F/S $1^{\text {st }}$ Row & 0.11128 & 0.06404 \\
2 & Secondary Super Heater F/S 16 $6^{\text {th }}$ Row & 0.14549 & 0.06339 \\
3 & Economizer Horizontal F/S & 0.00947 & 0.01513 \\
4 & Economizer Vertical F/S & 0.00840 & 0.00512 \\
5 & Platent Super Heater F/S & 0.05242 & 0.02424 \\
6 & Primary Super Heater F/S 1 $1^{\text {st }}$ Row & 0.06248 & 0.02191 \\
7 & Primary Super Heater F/S 20 Row & 0.02767 & 0.00312 \\
8 & Wall Tube F/S & 0.01863 & 0.02246 \\
\hline
\end{tabular}



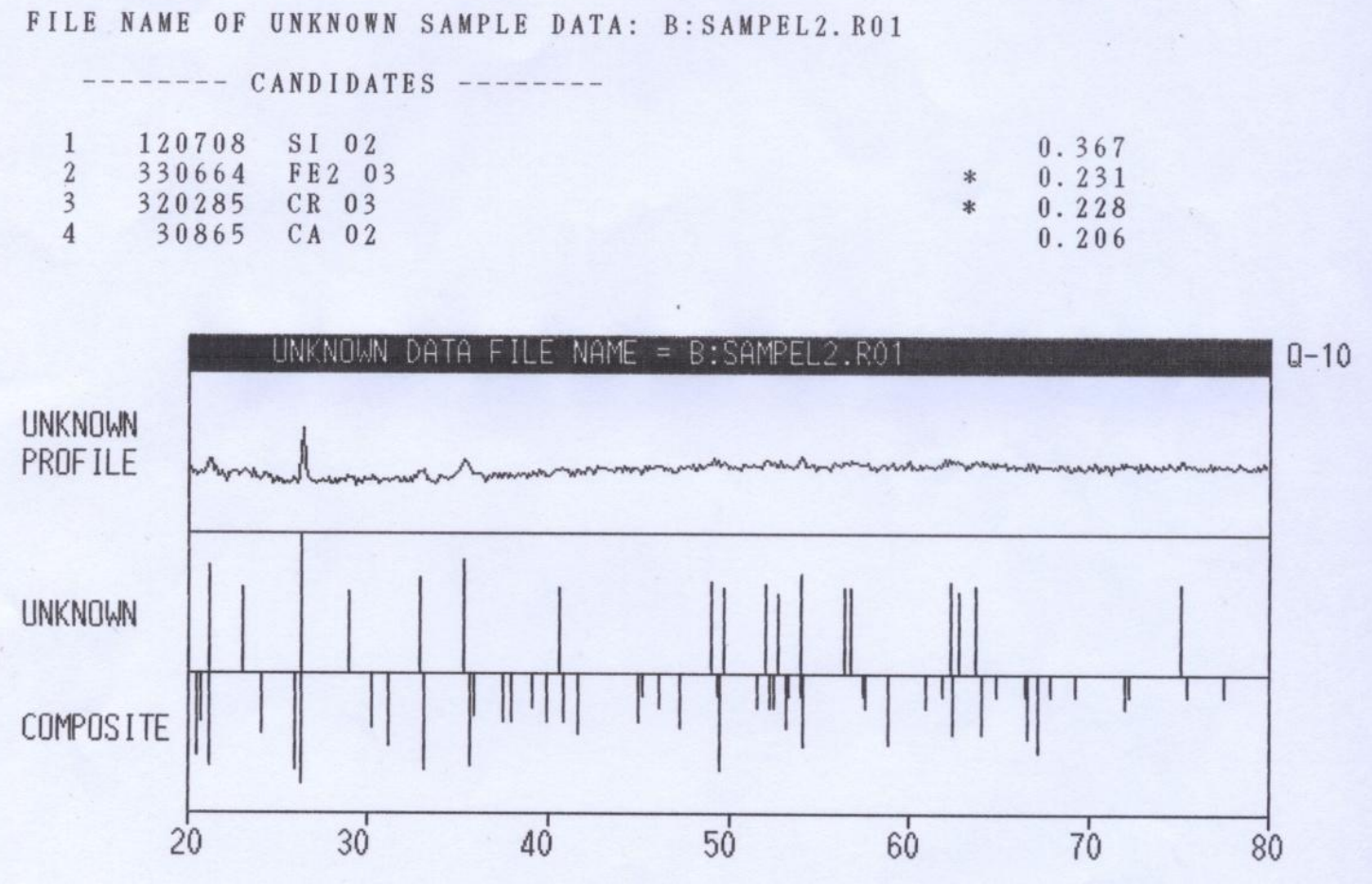

Gambar 9 : Hasil Uji Kerak pada Secondary Superheater F/S $16^{\text {th }}$ Row

\section{PEMBAHASAN}

Dari hasil pemeriksaan metalografi di laboratorium maupun dilapangan terhadap material pipa ketel, diketahui bahwa material pipa ketel gambar 4 strukturnya cenderung berupa ferrite dan spheroidisasi pearlite ${ }^{(1)}$, pada permukaan luar maupun dalam terlihat adanya lapisan kerak yang cukup tebal (gambar 6 \& 7), sehingga timbul serangan korosi merata (general corrosion $)^{(2)}$.

Selain itu pada tube Secondary Super Heater F/S Row $16^{\text {th }}$ permukaan luar dan dalam terserang korosi sumuran (pitting corrosion) ${ }^{(4)}$, sedangkan pada tube Economizer Horizontal F/S dan Platent Super Heater F/S pada bagian tengah dan dalam mengandung graphit (gambar 5).

Secara keseluruhan batas butiran masih terlihat jelas, dan tidak diketemukan adanya ciri-ciri kerusakan creep, menurut bentuk struktur seperti tersebut diatas termasuk kelas $C$ dan ada yang mengarah ke $D .^{(14)}$

Hampir keseluruhan tube boiler strukturnya telah mengalami perubahan dari normal ferrite dan pearlite menjadi ferrite dan speroidisasi pearlite, dimana morphology dari pearlite yang semula berbentuk memanjang (lamellar atau mirip daun) berubah menjadi spheroidisasi (globular atau membulat) ${ }^{(5)}$, serta mengandung graphit.

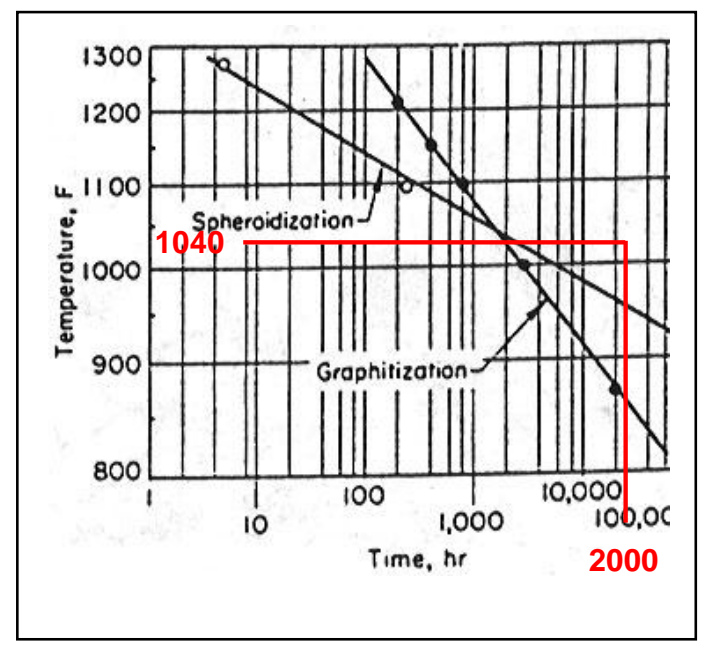

Gambar 10. Hubungan antara temperatur \& waktu pada dekomposisi pearlit dengan kaitan dari speroidisasi dan graphitisasi.

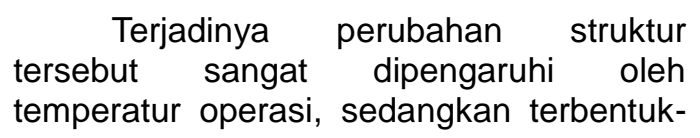


nya graphit disebabkan oleh terjadinya dekomposisi pearlite (iron carbide) menjadi ferrite dan graphit $^{(6)}$, Dalam kasus ini, keduanya terjadi secara bersamaan dan dari gambar 8 dapat diketahui bahwa temperatur operasi tube diperkirakan \pm 560 ${ }^{\circ} \mathrm{C}$ dan lama pengoperasian di atas 2000 jam.

Terbentuknya lapisan kerak (tabel 8) pada permukaan luar tube karena adanya jilatan lidah api (flame impingement) akibat pembakaran gas (gas burners) yang tidak sempurna. Kerak yang terbentuk pada permukaan luar tube berupa kerak oksida besi (iron okside) ${ }^{(7)}$,. Sedangkan lapisan kerak pada permukaan dalam tube terbentuk karena kualitas air didalam tube kondisinya dibawah standar operasi, seperti $\mathrm{PH}$, konduktifitas dan alkali. Dengan adanya kualitas air demineralisasi yang kurang baik yaitu mengandung unsur Chlor (Cl) dan Sulfur (S) yang terbawa oleh air (gambar 9), dengan kecepatan aliran fluida yang lambat akan memudahkan terbentuknya lapisan kerak pada permukaan luar dan dalam tube ${ }^{(8)}$, dan akan menghambat perpindahan panas antara gas yang terbakar untuk memanasi tube dan fluida yang mengalir didalam tube ${ }^{(9)}$,. Akibatnya secara ideal dapat meningkatkan temperatur hingga melampaui temperatur disain.

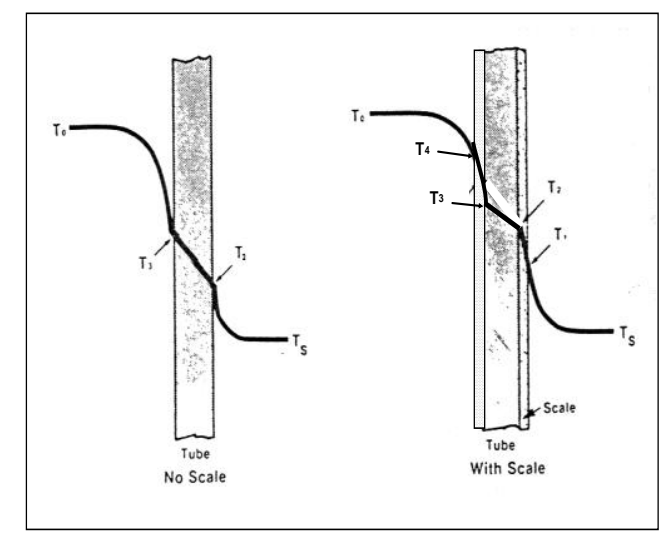

Gambar 11 : Ilustrasi profil temperatur dari temperatur gas pembakar (To) terhadap aliran fluida (Ts) yang mengalir didalam pipa.

Bila temperatur tube telah melampaui temperatur disain dan berlangsung dalam jangka waktu yang cukup lama, maka material tube akan mudah mengalami perubahan, misal dekarburisasi (hilangnya unsur carbon pada struktur) ${ }^{(10)}$,. Dengan adanya perubahan karakteristik dari material tube tersebut, maka kekuatan mekanis dari tube cenderung akan mengalami penurunan ${ }^{(11)}$,. Dalam kondisi tersebut maka tube tidak akan mampu menerima tekanan operasional fluida dari dalam. Dengan kondisi seperti tersebut diatas maka terjadi penurunan kekuatan pada tube boiler, dalam hal ini dapat terlihat juga dari hasil uji tarik dan uji kekerasan pada masing-masing tube, walaupun hasil uji tarik masih sesuai dengan standar, akan tetapi nilai kekerasannya berada jauh dibawah nilai maksimumnya (table 6).

Dengan adanya lapisan kerak yang cukup tebal pada permukan luar dan dalam tube juga serangan korosi merata / general corrosion, (gambar 6 \&7), sehingga terjadi pengurangan ketebalan. Selain itu pada permukaan luar dan dalam beberapa pipa, juga terjadi kerusakan akibat korosi yang terlokalisir berupa korosi sumuran (pitting corrosion) ${ }^{(1)}$.

Dari hasil pemeriksaan ketebalan kerak pada permukaan diameter dalam dan luar yang masih berada dibawah standar yaitu $15 \mathrm{mg} / \mathrm{cm}^{2}$. Begitu pula dari hasil pemeriksaan kerak dengan metoda EPMA dan XRD yang menunjukkan bahwa lapisan protektif pada permukaan tube telah mengalami kerusakan oleh serangan korosi akibat reaksi antara material tube dengan oksigen membentuk $\mathrm{Fe}_{2} \mathrm{O}_{3}$ (hematite) yang dikenal dengan General Corrosion ${ }^{(12)}$, serta dengan ditemukannya unsur Chlor pada tube Primery Superheater F/S $20^{\text {st }}$ Row, Platen Superheater F/S, dan Secondary Superheater $\mathrm{F} / \mathrm{S} 1^{\text {th }}$ Row dan atau unsur Sulphur pada tube Primery Superheater F/S $1^{\text {st }}$ Row, Secondary Superheater F/S $16^{\text {th }}$ Row, dan Economizer Horizontal F/S, maka serangan korosi sumuran (Pitting Corrosion) akan terjadi pada permukaan dalam tube. Selain itu pada Economizer Horizontal F/S, Platent Superheater F/S, Secondary Superheater F/S $1^{\text {th }}$ Row, dan Primery Superheater F/S 20 Row ditemukan adanya unsur Tembaga (Cu). Hal ini menunjukkan bahwa salah satu 
komponen dari plant (sebagai contoh condensor) telah mengalami serangan korosi akibat pengaruh dari air umpan yang mengandung Chlor.

Dari hasil pemeriksaan EPMA dan XRD pada lapisan kerak yang terdapat pada pipa menunjukkan adanya unsur Silica, dimana unsur Silica tersebut akan membentuk suatu fenomena yang disebut Carryover $^{(17)}$. Carryover dari unsur Silica merupakan masalah utama, khususnya dalam tekanan boiler subkritis, dimana kelarutan dari Silica dalam steam akan lebih tinggi daripada garam-garam lainnya dan metal oksida. Kelarutan Silica dalam steam sangat dipengaruhi oleh $\mathrm{PH}$ air boiler. Semakin tinggi $\mathrm{PH}$ air boiler, maka semakin rendah kelarutan Silica dalam steam, dan semakin tinggi pula konsentrasi Silica yang di izinkan dalam air boiler. Konsentrasi Silica dalam air boiler akan meningkat dikarenakan kualitas air demineralisasi yang kurang baik, serta adanya Coloid Silica. Oleh sebab itu $\mathrm{PH}$ dari air boiler harus dikontrol pada batas paling atas dari harga control, dengan cara meningkatkan blowdown rate.

Bilamana steam mengandung Silica dan garam-garam lainnya disuplai ke turbin, hal ini akan menyebabkan penurunan efisiensi turbin melalui kristalisasi dan pengendapan pada sudu turbin dan nozel. Secara umum konsentrasi silica dalam steam harus dipertahankan dibawah 0.02 $\mathrm{mg} / \mathrm{l}$ untuk mencegah pengendapan silica pada turbin ${ }^{(17)}$,.

Fenomena seperti tersebut diatas adalah biasa terjadi pada tube Boiler yang beroperasi pada temperatur minimum (500 -C) dalam jangka waktu yang cukup lama atau pada temperatur operasi yang mencapai $\pm 700 \stackrel{\circ}{\circ} \mathrm{C}$ dalam jangka waktu yang lebih pendek.

Secara umum hasil uji kekerasan pada beberapa pipa yang diperiksa mengalami penurunan, begitu pula hasil pengukuran ketebalan juga mengalami penipisan. Sedangkan hasil pemeriksaan struktur mikro pada beberapa tube (lihat gambar 4, 5, 6 \& 7), dapat dikategorikan adanya perubahan ${ }^{(14)}$. Akan tetapi hasil uji tarik beberapa tube boiler (table 3) masih sesuai dengan standard (table 2), dan hasil uji bending pada beberapa tube boiler juga tidak diketemukan adanya kerusakan atau cacat lainnya. Maka dapat dikatakan bahwa tube Boiler kelayakan operasinya sangat dipengaruhi dari laju korosi yang terjadi.

\section{KESIMPULAN}

Berdasarkan dari hasil pemeriksaan dan pengujian, maka dapat ditarik kesimpulan secara keseluruhan struktur mikro pipa ketel cenderung berupa ferrite dan spheroidisasi pearlite, batas butiran masih terlihat jelas, pada permukaan luar maupun dalam terlihat adanya lapisan kerak yang cukup tebal dan terlihat serangan korosi merata (general corrosion).

Sedangkan tube Secondary Super Heater $\mathrm{F} / \mathrm{S} 1^{\text {st }}$ Row dan Economizer Vertical F/S pada permukaan dalam strukturnya mengalami dekarburisasi, sedangkan tube Secondary Super Heater F/S $16^{\text {th }}$ Row pada permukaan luar dan dalam terserang korosi sumuran (pitting corrosion), sedangkan tube Economizer Horizontal F/S dan Platent Super Heater F/S mengandung graphit.

Hasil uji tarik pipa ketel masih sesuai dengan standard (tabel 1), dan hasil uji bending pipa yang diperiksa juga tidak diketemukan adanya penyimpangan dan secara umum hasil uji kekerasan pada beberapa pipa yang diperiksa mengalami penurunan, begitu pula hasil pengukuran ketebalan pada beberapa pipa yang diperiksa juga mengalami penipisan.

Adanya kerak pada pipa ketel menunjukkan bahwa air umpan ketel selama beroperasi pernah berada dibawah standar yang diijinkan dan perubahan beban thermal yang cukup tinggi. Ini diperlihatkan adanya elemen silica, tembaga, khlorida, sulfur, dan kalsium pada hasil pemeriksaan dengan metoda EPMA dan XRD.

Dari beberapa kesimpulan hasil pemeriksaan yang dilakukan tersebut dan yang sangat signifikan adanya lapisan kerak yang cukup tebal, serangan korosi merata juga sumuran serta terjadi penipisan ketebalan pipa akibat dari adanya elemen korosif pada air. 


\section{DAFTAR PUSTAKA}

1. Hadi Sunandrio, "Serangan Korosi Pada Pipa Almunium Radiator Kendaraan Roda Empat." Volume 15 no 2 Material Komponen dan Konstruksi" Desember 2015.

2. Jones D A. "Priciples and Prevention of Corrosion", Macmillan Publishing Company, New York 2008.

3. Heint P. Bloch Fred K. Geitner "Machinery Failure Analysis and Troubleshooting", Gulf Publishing Company, Houston, Texas 2011.

4. R. Winston Revie, "Corrosion and Corrosion Control", John Wiley \& Sons, United States of America, 2008.

5. Anual Book of ASTM Standards, Vol. 01.01, "Steel Piping, Tubing, Fitting", American Society for Testing and Material, Philadelphia, 2006.

6. Z. Szklarska Smialowska, "Pitting Corrosion of Metals", National Association of Corrosion Engineers, 2005.

7. R. Winston Revie, "Uhlig's Corrosion Handbook", John Wiley \& Sons, United States of America, 2006.

8. Hadi Sunandrio, Laili Novita Sari, "Serangan Korosi Sumuran Pada Roll Bearing Pipa Distribusi " volume 11 no 2 Material Komponen dan Konstruksi Desember 2011.

9. Sundjono, "Fenomena Kegagalan Akibat Korosi Pada Pipa Economizer Dari Baja Carbon" volume 15 no 2, Korosi LIPI 2006

10. M.Syahril "Fenomena Korosi Dibawah Isolaso Panas Pada Material TP 321 Pipa Uap Hidro Karbon " volume 16 no 2 Korosi LIPI Oktober 2007.

11. Nizamul Latif, "Kerusakan Korosi Pipa Saluran Kimia Akibat Kesalahan Material "Edisi $V$ no 8 Material Komponen dan Konstruksi" Desember 2005.

12. DN. Adnyana "Stress Corrosion Cracking of Stainless Steel, Hose Bellows "volume 15 no 2, Korosi LIPI 2006

13. Laili Novita Sari "Transgranular Stress Corrosion Cracking Penyebab Kegagalan Poros Ulir, Volume 10 no 2, Material Komponen dan Konstruksi. 2010

14. Ilham Hatta "Aplikasi Mikro-Analisis dan Fraktografi untuk Menentukan Kualitas Produk Manufaktur dan Penyebab Kerusakan Suatu Komponen". Prosiding Pertemuan
Ilmiah Pengetahuan dan Teknologi Bahan ISSN 1411-2213 - 2012

15. Greaves, R.H. and Wrighton, H., Practical Microscopical Metallography, Chapman and Hall Ltd. New Fetter Lane, London, 11 (1998).

16. Bahadori, A \& Vuthaluru, HB, 'Prediksi silika carry-over dan kelarutan dalam steam boiler menggunakan korelasi sederhana', Terapan Rekayasa Termal, vol. 30, hlm. 250-253. 2010.

17. ASME Boiler \& Pressure vessel Code an International Code, Section II Material 2015. 
M.I. Mat. Konst. Vol. 16 - Juni 2016 - Hal 17-27 